\title{
Innovation and Entrepreneurship for the Diversification and Growth of the Gulf Cooperation Council Economies
}

\author{
Hela Miniaoui ${ }^{1}$, Daniele Schilirò ${ }^{2}$ \\ ${ }^{1}$ Gulf Studies Center, Qatar University, Qatar \\ ${ }^{2}$ Department of Economics, University of Messina, Italy \\ Correspondence: Daniele Schilirò, Department of Economics, University of Messina, Italy.
}

Received: February 16, 2017

Accepted: August 11, 2017

Online Published: August 14, 2017

doi:10.11114/bms.v3i3.2594

URL: https://doi.org/10.11114/bms.v3i3.2594

\begin{abstract}
The Arab States of the Gulf region have vast reserves of petroleum. The reduction in oil prices since the summer of 2014, and their volatility pose strong challenges to the six economies of the Gulf Cooperation Council (GCC). In the present contribution, we argue that, in the long-run, diversified economies perform better than mono-sector economies. Also, innovation and entrepreneurship are key drivers for the diversification and growth of GCC economies. More specifically, in this article we analyze the innovation performance of the GCC economies and we consider their innovation strategies. In addition, we provide an overview of entrepreneurship in the GCC countries to grasp its current state, aiming at identifying the conditions to foster entrepreneurship in order to develop the non-oil private sector. Finally, we discuss the policies that would be required to boost innovation and stimulate entrepreneurship in the Arab States of the Gulf with the aim of diversifying their economies and enhancing their growth.
\end{abstract}

Keywords: innovation, entrepreneurship, diversification, growth, GCC countries

JEL Classification: L10, L26, M13, O31, O38

\section{Introduction}

The Arab States of the Gulf Cooperation Council (GCC) have vast reserves of petroleum. The reduction in oil prices since the summer of 2014, and their volatility pose strong challenges to the GCC economies, whose public revenues and living standards are highly dependent on oil. For these oil-producing countries, in fact, the decline in oil prices is having significant effects on production, consumption and public finance, creating an uncertain economic environment.

Several studies, including those from the World Bank (e.g. Lederman, Maloney, 2007; Hesse, 2008) and the IMF book by Cherif, Hasanov, Zhu, (2016) confirm that diversified economies do better than mono-sector economies over the long run. In this contribution, we share the theoretical point of view that innovation and entrepreneurship are major factors that contribute to diversification of the GCC economies and enhance their degree of competitiveness and economic growth. Since competition in the global economy has increasingly become knowledge and innovation driven, technological advance and innovation, in the widest sense, have become the keys of competitiveness and growth in traditional industrial sectors, in high-tech sectors, and in services, also contributing to the creation of new economic activities. Furthermore, entrepreneurship spurs economic growth and employment by favoring a competitive environment, creating new ventures in many sectors and supporting a globalized market infrastructure.

More specifically, in this contribution we highlight the relevance of diversification for the growth of GCC economies. Also, we analyze the innovation performance of the GCC countries and we consider their innovation strategies. In addition, we provide an overview of entrepreneurship in the GCC countries to grasp its current state. Furthermore, we seek to identify the conditions to increase entrepreneurship and qualify the human capital with the aim developing the non-oil private sector of the GCC economies. To support our analysis, we take into account of several data and surveys sources. Finally, we discuss the necessary policies to be implemented to promote innovation and stimulate entrepreneurship in the GCC countries in order to diversify their economies and to enhance their growth. 


\section{Diversification in the GCC Economies}

The Gulf Cooperation Council is an oil-based region of 6 countries, Bahrain, Kuwait, Oman, Qatar, Saudi Arabia, UAE, with the largest proven crude oil reserves in the world representing about $36 \%$ of the world's total. This region ranks as the largest producer as well as exporter of petroleum playing a leading role in the world. Therefore, the Gulf region is a vital source for the global economic stability.

The economic model of GCC countries relies on oil and gas as the main sources of fiscal revenues (in 2015 oil and gas revenues accounted for $46 \%$ of the six Gulf nations' GDP) and exports (oil and gas represent around $75 \%$ of total exports), where the government is the dominant player in the economy that receives the revenues from oil exports and manage the revenue distribution. The drop in oil prices has determined rising budget deficits and dampening economic growth in the GCC countries, but it has also weakened the conditions of the corporate and infrastructure sectors, and make more difficult to fund investments. The present economic situation of lower and volatile oil prices, widening fiscal deficits, rising competition and high youth unemployment represents a problematic economic scenario for an area that is still controlling a very important share of the world's energy supply.

The IMF (2016) reports that GCC economies as a whole have lowered their rate of growth to $1.8 \%$ in 2016 from $3.3 \%$ in 2015 , due to the tight fiscal policy, weak private sector confidence, and low liquidity in the banking sector. The current situation in the GCC countries necessitates not only a shift from the classic rentier state economy, involving a reduction in their dependence on oil revenues, but also a shift from a non-oil output that consists overwhelmingly of non-tradables (Cherif, Hasanov, Zhu, 2016). There is a need for a deep transformation of the GCC economies in the medium-long term towards a private sector development and, more specifically, towards the tradable sector that should involve a higher productivity growth. In addition, it is necessary that an adjustment in the public budgets to be anchored by credible medium-term fiscal consolidation plans. This requires limiting current spending, including wage and subsidy bills. However, since fiscal deficits have reached 13.2\% of GDP in 2015 (IMF, 2015), the Gulf countries are currently involved in fiscal consolidation, which translates in spending cuts, increases in taxation (new VATs on housing, electricity, hotels, etc.) and removing subsidies (on fuel, electricity, some food items, etc.). The fiscal restructuring is particularly evident in Saudi Arabia, Kuwait and the UAE, where huge spending cuts on subsidies have just started. Nevertheless, macroeconomic imbalances in the region will continue not only in 2016, but also in the following years.

Restoring fiscal balances is not sufficient to guarantee the development of the economies of the region. Rather, major reforms must be implemented in many areas, such as innovation, entrepreneurship, the labor market, education, financial markets, private capital growth, and so forth, to promote an efficient allocation of resources in the economy, boost job creation and nurture non-oil private sectors. So far, the States of the Gulf Cooperation Council, which have become high-income countries, have experienced some of the world's highest public investment in physical capital. Using oil receipts, they have financed massive physical infrastructure investment. But the distribution of oil revenues within the economy has tended to crowd out non-oil tradable production. In addition, the production of non-tradables has proved more convenient and less risky for firms because they could have benefited from the rapid growth in government spending, while the easy availability of low skilled, low-wage foreign labor has helped extract larger rents. Unfortunately, this model hinders the move to a knowledge-driven economy, where skills and capabilities are key and affect productivity; but it also does not allow a shift to increasingly high value-added industries. Moreover, the availability of public sector jobs has discouraged nationals from pursuing entrepreneurship and private sector employment.

The overall volatility in the economy due to the changes in the price of oil and its ensuing spillover effects can be mitigated with the diversification and development of high-value-added production, but also through the increase in exports of (non-oil) goods and services of high quality (Schilirò, 2013). The diversification of GCC economies would help to create more employment in private sector for nationals, especially high-value-added jobs in industries and services. Consequently, GCC countries must pursue economic diversification and achieve a sustainable growth model that requires a diversified tradable sector (Cherif, Hasanov, Zhu, 2016). The main strategies to be followed in order to reach this goal are: favoring innovation and stimulating entrepreneurship. Diversification will be more effective if it is able to increase the quality, sophistication and differentiation of the exports, and support workers in acquiring the relevant skills and education to boost productivity. In addition, to spur growth these countries should continue building infrastructure that could provide the platform for economic diversification.

Most of the oil producing countries have changed the structure of their economies in the last decade, making significant investment in health, education and infrastructure, and implementing reforms to the business environment. The GCC countries have also devised long-range economic and social development strategies that emphasize the importance of economic diversification. These strategies aim to promote sustainable development, reduce dependence on oil revenues, and increase private sector job creation for nationals. In this respect, economic diversification is considered to be an 
important stepping-stone to achieving all three objectives. Thus, we have the long-term strategy Vision 2020 in Oman, Vision 2021 in the United Arab Emirates, Vision 2030 in Bahrain, Qatar National Vision 2030 in Qatar and the new Vision 2030 in Saudi Arabia. While some variation exists across countries, economic diversification and development efforts are geared toward boosting the human capital of nationals and developing high-productivity industries and services that require high-skilled labor. Although all the GCC countries embarked upon a policy of economic diversification, the only clear 'success story' is UAE.

The expansion of the private sector and the diversification away from oil that are needed to absorb the growing workforce have so far proven elusive in many cases. Though some progress has been made, most economies in the region are still deeply dependent on the capital-intensive hydrocarbon sector, which generates limited direct employment. The private sector itself is highly reliant on government spending, but it needs to become self-sustaining through increased competitiveness in the internal market but also in export markets. Thus, it is crucial to change the incentive structure within the economy to create the necessary shift towards the private non-hydrocarbon sector (Callen et al., 2014; Cherif, Hasanov, Zhu, 2016). Nationals must be stimulated with appropriate incentives to improve their skills, and making those skills more relevant to the private sector by improving the quality of education. Experience and empirical analysis show that diversification usually takes a long time, and it undergoes a decisive push just as revenues from oil start to decrease (Callen et. al., 2014). However, success or failure of diversification appears to depend on the implementation of appropriate policies. Callen et al. (2014) suggest several targeted measures to improve the business environment in order to alter the current incentives that avoid the production of non-oil tradable goods. Among the measures, they propose reorienting public spending, strengthening the role of private sector competition, developing backward and forward linkages across sectors with a comparative advantage, and implementing labor market reforms to incentivize private sector employment of nationals and improvements in productivity. Mitra et al. (2016) stress the need of streamlining business regulations and reducing bureaucratic red tape to significantly lower the cost of doing business, and raise the efficiency of government services. These authors highlight the importance of developing financial markets for fostering the accumulation of physical capital in the private sector-also critical for economic diversification, since financial market development hinges on improving access to finance. Still, Hamdi and Hakimi (2015) carried out a significant empirical analysis concerning financial market developments and growth for the Middle East and North Africa (MENA) region. They underline the crucial role of financial markets and banks for economic growth. Their results reveal the existence of a positive relationship between financial development and growth, and between banking development and economic growth through improvement of financing to the private sector. Thus, Hamdi and Hakimi (2015) suggest changes, reforms and modernization of financial markets in the MENA region. We broadly agree with these measures and proposals. However, besides these proposals, in order to strengthen the private sector and diversify the economies in the GCC countries, it is fundamental to create the conditions for an environment conducive to innovation and also stimulate entrepreneurship with particular focus on small and medium enterprises (Schilirò, 2015).

\section{Innovation Strategies in the GCC Countries}

Innovation is one of the basic factors for economic diversification and a crucial driver in boosting growth. Innovation is also seen as key to addressing pressing societal problems such as pollution, health issues, and unemployment. Peter Drucker (1985) viewed innovation as the tool or instrument used by entrepreneurs to exploit change as an opportunity. Innovation involves more than just science and technology. It involves discerning and meeting the needs of customers. Improvements in marketing, distribution, and service are innovations that can be as important as those generated in laboratories involving new products and processes. Although innovation is largely driven by entrepreneurs and the private sector, government action can play a strategic supportive role. For the GCC economies that aim to become innovation driven, knowledge is a key factor and an essential part of any innovation strategy, thus investing in knowledge is a must. This is true for the private sector, although it may consider such an investment risky and expensive. It is an obligation for the government that should address the failure of the private sector by investing adequately in knowledge, to demonstrate the potential returns of such investment. A strategy of successful innovation by the government consists of a coherent approach, which seeks to coordinate different policies towards scientific research, information and communication technology (ICT) investments, education, intellectual property (IP), taxation, etc. in an integrated manner to drive economic growth (Cornell et al., 2016).

One important goal of any innovation strategy is to enhance innovation capacity and move the country toward the global frontier of innovation. Porter and Stern (2001) have argued that the innovation capacity of a country depends on strengths along dimensions such as the quality of human resources and innovation-oriented corporate investment. Furman, Porter and Stern (2002) found that public policy plays a relevant role in shaping a country's innovative capacity. Policy choices such as the extent of IP protection and openness to international trade are very significant, but also policies that encourage human capital investment in science and engineering are important. Moreover, inputs devoted to innovation such as R\&D manpower and spending, the share of research performed by the academic sector 
and funded by the private sector, and the degree of technological specialization contribute significantly to developing the innovation capacity of a country.

In general, innovation system literature puts great emphasis on the role of human capital and institutions for innovation and development, but very often these innovation input factors seem to be the most difficult of all inputs in which to achieve good results. GCC countries are aware that technology adoption alone is no longer sufficient to maintain a high-income level and boost economic growth, thus they have developed innovation policy programs. An innovation system approach is the result of complex interactions among all innovation actors, policies and institutions. According to this approach, apart from incentivizing research, the framework conditions for innovation must be improved. The framework conditions include the business environment, access to finance, competition, and trade openness. Collaboration is another essential requirement; consequently, collaborative research projects, public-private partnerships, and clusters involving the innovation actors should be targeted. There is the need to create strong human capital, and a research base that includes research infrastructures, sophisticated firms and markets, innovation linkages, and knowledge absorption as well. Yet, an important factor is legislation that supports future innovation and the related markets, along with the international harmonization of regulations for new technologies so they can diffuse more rapidly. Thus, the innovation policy involves many policy domains (e.g., education, international trade) and various institutional reforms.

According to Furman, Porter and Stern (2002), one of the key factors of innovative capacity that contributes the country being innovative at the global frontier is $R \& D$. Therefore, patents can represent valuable innovative output. It is interesting to look at the patent activity in the GCC countries. Patents, in fact, can provide a uniquely detailed source of information on inventive activity. Patent statistics, viewed as an indicator of R\&D output, are an imperfect proxy of the rate of technological innovation that is unobservable (Eaton and Kortum, 1999; Kortum, 1997). In the Tables below we show the number of patents in the GCC countries.

Table 1, in particular, shows the number of patent applications per GCC from 1988 to 2014. This table highlights the technological strength of the various GCC countries. Saudi Arabia is the first country in the ranking and it is very distant from the other countries, having the highest number of patent applications (1643) and the overwhelming percentage over the total $(86.8 \%)$. The second country in this ranking is the UAE, but it has only 89 patent applications and a percentage over the total of $4.7 \%$. The country with the smallest number of patent applications is Oman (17).

Table 1. Number of patent applications per GCC country (from 1998 to 2014)

\begin{tabular}{lccccccc}
\hline GCC Country & Bahrain & Kuwait & Oman & Qatar & Saudi & UAE & All \\
\hline & & & & & Arabia & & GCC \\
Number of Patents & 29 & 69 & 17 & 46 & 1643 & 89 & 1893 \\
$\begin{array}{l}\text { Percentage } \\
\text { of Patents }\end{array}$ & $1.5 \%$ & $3.6 \%$ & $0.9 \%$ & $2.4 \%$ & $86.8 \%$ & $4.7 \%$ & $100 \%$ \\
\end{tabular}

Source: GCC Patent Office ${ }^{1}$

Table 1 highlights the technological strength of the various GCC countries. Saudi Arabia is the first country in the ranking and it is very distant from the other countries, having the highest number of patent applications (1643) and the overwhelming percentage over the total $(86.8 \%)$. The second country in this ranking is the UAE, but it has only 89 patent applications and a percentage over the total of $4.7 \%$. The country with the smallest number of patent applications is Oman (17).

These patent data contribute to our understanding of the innovation system and the factors that support economic growth. They can also be considered the expression of the stock of knowledge in each GCC country in the period 1998-2014, while the total number for all GCC (1893) represents the stock of knowledge in the region in the same period. The data in Table 1 can be interpreted as an imperfect proxy of the rate of technological innovation, even if they actually represent the potential towards innovation.

Table 2 instead shows the patents delivered per GCC country from 1998 until February 2015. The numbers shown are smaller than in Table 1. In terms of percentage over the total of all GCC, comparing Table 2 with Table 1, the weight of Bahrain, Kuwait, Qatar, UAE slightly increases while that of Oman and Saudi Arabia decreases.

\footnotetext{
${ }^{1}$ The GCC Patent Office is a regional patent office based in Riyadh, Saudi Arabia, within the Secretariat General of the Gulf Cooperation Council (GCC). The GCC Patent Office grants patents valid in all GCC member states.
} 
Table 2. Number of patents delivered per GCC country (until February 2015)

\begin{tabular}{lccccccc}
\hline GCC Country & Bahrain & Kuwait & Oman & Qatar & Saudi Arabia & UAE & All GCC \\
\hline Number of Patents & 5 & 9 & 1 & 7 & 197 & 13 & 232 \\
Percentage of Patents & $2.15 \%$ & $3.87 \%$ & $0.43 \%$ & $3.01 \%$ & $84.91 \%$ & $5.6 \%$ & $100 \%$ \\
\hline
\end{tabular}

Source: GCC Patent Office

Patents are usually classified according to technological categories. The classification provided in Table 3 considers the main technical fields in the GCC region.

Table 3. Number of patent applicants per fields in the GCC region from 1998 to 2014

\begin{tabular}{lccccc}
\hline Fields & Chemistry \& Engineering Chemistry & Pharmaceutics \& Electrical & Oil \& Gas & Mechanical \& Electrical Engineering & All Fields \\
\hline Number of Patents & 1491 & 459 & 442 & 800 & 3252 \\
\hline
\end{tabular}

Source: GCC Patents Office

Table 3 clearly shows that the field in which the number of patents is highest is Chemistry and Engineering Chemistry (1491), since this field is more related to petroleum realm. Mechanical and Electrical Engineering is also a field where the number of patents is considerable (800). Pharmaceutics and Technical (549) and Oil and Gas (442) are the fields with a number of patents are far lower than the first two.

These data highlight a fairly degree of innovative vitality in the GCC countries, especially in Saudi Arabia, followed at a distance by the UAE and Kuwait, and it is concentrated in the fields of Chemistry and Engineering Chemistry, and Mechanical and Electrical Engineering. The whole GCC region need to further support patent activity and innovation through an appropriate innovation policy. However, innovation policy is strictly related to entrepreneurship and to the capacity to create an innovation culture among businesses, students, and society at large.

\subsection{Evidence from the Global Innovation Index in the GCC Countries}

The Global Innovation Index (GII), released by Cornell University et al. (2016), offers a global view on innovation, providing a tool of action for decision makers and for monitoring the impact of innovation policies. The 2016 GII is based on data available for 128 countries. The GII consists of two Sub-Indexes, the Innovation Input Sub-Index and the Innovation Output Sub-Index.

Table 4 show the top three economies and the rankings of GCC countries according to the Global Innovation Index rankings in 2016. The top three economies are Switzerland $\left(1^{\text {st }}\right)$, Sweden $\left(2^{\text {nd }}\right)$, and United Kingdom $\left(3^{\text {rd }}\right)$. The Gulf Cooperation Council (GCC) countries are, except Kuwait and Oman, in the first half the ranking: The United Arab Emirates, Saudi Arabia, Qatar, and Bahrain. In spite of that, the United Arab Emirates, Saudi Arabia, Qatar, Bahrain, Kuwait and Oman, show below-par performances compared to their income levels.

Table 4. Global Innovation Index rankings in 2016 (Top and GCC countries)

$\begin{array}{r}\text { Switzerland }\left(1^{\text {st }}\right) \\ \text { Sweden }\left(2^{\text {nd }}\right) \\ \text { United } \operatorname{Kingdom}\left(3^{\text {rd }}\right) \\ \text { United Arab Emirates }\left(41^{\text {st }}\right) \\ \text { Saudi Arabia }\left(49^{\text {th }}\right) \\ \text { Qatar }\left(50^{\text {th }}\right) \\ \text { Bahrain }\left(57^{\text {th }}\right) \\ \text { Kuwait }\left(67^{\text {th }}\right) \\ \text { Oman }\left(73^{\text {th }}\right) \\ \hline \text { Source: Cories }\end{array}$

Source: Cornell University et al. (2016).

The GII metrics confirm a core principle of international policy literature: good innovation policies start with good innovation institutions. Another key message of the GII report is that innovation has become more internationalized and collaborative than ever before, so a rising share of innovation is carried out through global innovation networks and leveraging talent worldwide.

Table 5 lists the top three economies and the rankings of the GCC countries relative to the Innovation Input Sub-Index. The top countries are innovation leaders since they have succeeded in creating well-linked innovation systems, where investments in human capital thrive in fertile and stable innovation infrastructures to create high levels of innovation outputs. 
Table 5. Innovation Input Sub-Index in 2016 (Top and GCC countries)

\begin{tabular}{c} 
Singapore $\left(1^{\text {th }}\right)$ \\
Hong Kong $($ China $)\left(2^{\text {nd }}\right)$ \\
United States of America $\left(3^{\text {rd }}\right)$ \\
United Arab Emirates $\left(25^{\text {th }}\right)$ \\
Qatar $\left(41^{\text {st }}\right)$ \\
Saudi Arabia $\left(43^{\text {th }}\right)$ \\
Oman $\left(63^{\text {th }}\right)$ \\
Kuwait $\left(78^{\text {th }}\right)$ \\
\hline
\end{tabular}

Source: Cornell University et al. (2016).

For the GCC countries, the United Arab Emirates (UAE) is the country with the highest index of Innovation (25th), and it is relatively well placed in the total raking. The UAE is characterized by a collaborative effort among public and private stakeholders, which is driving a move towards diversification where entrepreneurs and small- and medium-sized enterprises play an important role. The UAE leaders' ambition of fostering innovation and knowledge-driven growth is documented in the country's Vision 2021 national strategy.

Qatar is second in the ranking among the GCC economies. In this country access to finance is world class and businesses and individuals use latest technologies, including the Internet, widely. Government procurement plays a key role in promoting innovation, yet the patenting rate of Qatari nationals remains low.

Saudi Arabia is third among the GCC economies. The country is strongly dominated by oil, but low oil prices are having a strong impact on Saudi's economy. Thus, the economy and its structure need to change (IMF, 2015). "Vision 2030" announced by the government in April 2016 and the National Transformation Plan (NTP) approved in June 2016 work in the direction of diversification and to foster innovation. A major idea behind the kingdom's "Vision 2030" is to create millions of new jobs and raise the participation of women in the workforce from $22 \%$ currently to $30 \%$ by 2030 . But also, to create new ventures in areas in the private sector that will generate revenues and reduce administrative barriers to entry, which are still high. The success of this new plan will be crucial to change the structure of the Saudi economy.

Bahrain, Oman and Kuwait are behind, since, in general, they suffer insufficient capacity to innovate and an inadequately educated workforce. Consequently, they need to strengthen the process of structural change of their economies and implement a more effective innovation policy. In particular, these countries need to improve institutions and prioritize the resources towards research and development, and also in education.

On the whole, the resource-rich GCC countries tend to exhibit relative shortcomings in major areas such as Institutions, Market sophistication, and Business sophistication. Thus, it is crucial to provide the framework conditions that stimulate a process of innovation and knowledge diffusion such as supportive institutions, good and widespread technical and tertiary education to enhance absorptive capacity, excellent provision of ICT property rights, and stronger links between publicly funded research institutes and private companies. Furthermore, these countries have large groups of micro and small businesses, operating far below the frontier of innovation, with low levels of human capital. Innovation and the adoption of better technologies will affect the productivity of these smaller producers with a positive impact on employment and economic growth. Most of these small firms are without patents, and have little experience in intellectual property protection. Usually, these firms try to reap the benefits of catching up through adoption and international technology transfer, instead of investing in R\&D. Among the various possible channels for transfer are imports of capital goods, subcontracting agreements, technical assistance programs, technology licensing contracts, and inward foreign direct investment. But any effort to successfully innovate and improve the technological level of the firms depends on the technological capabilities of the firms themselves (Furman, Porter and Stern, 2002). These capabilities include skills, experiences, attitudes, and schooling. Also, a broad consensus exists that the process of business internationalization triggers innovation and the development of capabilities (Altomonte et al., 2013; Cornell University et al., 2016; Schilirò, 2015).

In conclusion, GCC governments and enterprises can and must do more for innovation, particularly countries such Oman and Kuwait. Cornell University et al. (2016) suggest some principles that the innovation policy should follow to be successful, and this also applies to the GCC countries. First, the spurring of innovation must involve all sectors, not just high-tech production, including traditional sectors such as farming, retail, logistics and business services. Second, innovation activity should consider all points of the innovation value chain. In addition, countries need to enable 
disruptive innovation, which is often generated by new market entrants, especially those emerging in their own economies. Cornell University et al. (2016) emphasize the importance of S\&T which has reached a global dimension and the role of ICT, which is a general-purpose technology. The creation of key innovation inputs, such as skilled workforce and knowledge, and digital infrastructure are other crucial elements. In fact, digital innovation can significantly impact the growth of a country. The digital economy, with its stream of communication, ideas, and information, has tremendous value in its own right, but it also plays a role in enabling other, more traditional types of flows. Lastly, renewable energy is also an important field for innovation. All this can be a profitable way to innovate and diversify the economies and enhance growth in the GCC region.

\section{An Overview on Entrepreneurship in the GCC Countries}

Entrepreneurship is key for economic diversification, employment creation and sustainable growth especially in the GCC countries. Although for many decades economists have ignored the role of entrepreneurship in the economy, Joseph Schumpeter $(1939,1942)$ strongly contributed to its understanding, mainly in a development perspective. In addition, Schumpeter highlighted the virtuous combination of entrepreneurship and innovation. Acs (2006), Amorós and Bosma (2014) and Singer, Amoròs, Arreola, (2015) stress a number of advantages associated with entrepreneurship and innovation including the creation of new companies from investment in local economies, creating new jobs, increasing competitiveness and developing the instruments needed for the establishment and continuation of innovative companies. GEM surveys have confirmed that entrepreneurial activity in different forms (i.e. nascent, start-up) is positively correlated with the economic growth, but that this relationship differs along phases of economic development.

Recent literature shows that economists have realized that the degree to which the entrepreneur will engage in innovation depends on the size and functioning of the market. But the functioning of markets requires the action of institutions, such as property rights and rules to enforce contracts. A well-defined system of property rights and an apparatus of market regulation to ensure competition are "good" institutions, which help innovation and entrepreneurship, and favor the economic growth of a country (North, 1990; La Porta, et al., 1999; Acemoglou et. al., 2001).

We now focus on the report Entrepreneurship in the MENA Survey by Bayt (2015) that seeks to get insights about the current level of understanding and interest in entrepreneurship within the MENA region; therefore, it includes the GCC countries. The key information areas covered in the report are: current work preferences and reasons for being self-employed versus employed; current level of entrepreneurship in the region; the perceived barriers to starting a business; the ease of setting up their own business in current country of residence; and perception of entrepreneurs in the region. The number of respondents in the present survey was 8,164. As far as the research findings related to 'work style preferences' for the whole MENA region, $64 \%$ would prefer to be self-employed; moreover, the top reason for preferring self-employment is personal fulfillment (54\% of respondents).

Table 6 shows the respondents from the GCC countries and also the whole MENA region regarding 'work style preferences'.

Table 6.'Work style preferences' for GCC countries and the whole MENA region (percentage values)

\begin{tabular}{|c|c|c|c|c|}
\hline GCC & & respondents & & \\
\hline \multicolumn{5}{|l|}{ Countries } \\
\hline & $\begin{array}{c}\text { be self-employed/ have my own } \\
\text { business }\end{array}$ & $\begin{array}{l}\text { seek employment in a company } \\
\text { (work for pay) }\end{array}$ & $\begin{array}{c}\text { work in a family business (if } \\
\text { applicable) }\end{array}$ & others \\
\hline Bahrain & $74 \%$ & $22 \%$ & $2 \%$ & $2 \%$ \\
\hline Kuwait & $63 \%$ & $32 \%$ & $2 \%$ & $3 \%$ \\
\hline Oman & $61 \%$ & $32 \%$ & $1 \%$ & $6 \%$ \\
\hline Qatar & $66 \%$ & $30 \%$ & $3 \%$ & $1 \%$ \\
\hline Saudi Arabia & $67 \%$ & $28 \%$ & $2 \%$ & $3 \%$ \\
\hline UAE & $66 \%$ & $29 \%$ & $2 \%$ & $3 \%$ \\
\hline Whole Mean & $64 \%$ & $31 \%$ & $2 \%$ & $3 \%$ \\
\hline
\end{tabular}

Source: Bayt (2015)

The only GCC country in Table 6 that shows a result of 'be self-employed' significantly above that of the whole MENA region is Bahrain. Also, Saudi Arabia, Qatar and UAE are above. Oman is below, while Kuwait is nearly the same level of the whole MENA region. These results highlight a strong propensity towards self-employment and entrepreneurial activities within GCC countries. 
Another interesting result of the survey is that the majority of the respondents (over $60 \%$ ), who are currently employed in the private or public sector, think of starting their own business. 'More income' followed by 'greater independence' emerge as the top two reasons to start a business. On the contrary, respondents mainly prefer to seek employment in a company because of 'regular income' and for the 'stability of employment,' but also because 'no investment required.'

Regarding the choice of sector (public or private), the results of the respondents are that in some GCC countries (Kuwait, Oman, Saudi Arabia and UAE) the respondents are mostly inclined towards a private sector company, in accordance with the whole MENA region, while in others (Bahrain and Oman) the respondents are mostly inclined towards a public-sector company. In addition, if we look at the barriers that have prevented respondents from starting their own business, the most frequent answers are: 'inability to self-finance' and 'not being able to get financial support.' Thus, 'procuring startup finance' is by far the top concern for setting up a business. Another important result concerns the role of education in the entrepreneurial endeavors. In the GCC countries more than 7 in 10 respondents claim that the education they received has helped them develop an entrepreneurial attitude.

Table 7 indicates the first three industries as the 'most appealing industry for entrepreneurship'.

Table 7. First three industries preferred in the GCC countries (ranked in preference order)

\begin{tabular}{lccc}
\hline GCC countries & & first three industries & \\
\hline Bahrain: & Hospitality \& Leisure & Advertising/Marketing & Finance/Insurance/Real Estate \\
Kuwait: & Advertising/Marketing & Hospitality and Leisure & ITC \\
Oman: & Architecture \& Engin & Finance/Insurance/Real Estate & Hospitality \& Leisure \\
Qatar: & Architecture \& Engin & Hospitality \& Leisure & Finance/Insurance/Real Estate \\
Saudi Arabia: & ITC & Advertising/Marketing & Finance/Insurance/Real Estate \\
UAE: & Hospitality and Leisure & Advertising/Marketing & Architecture \& Engin \\
\hline
\end{tabular}

Source: Bayt (2015)

Each GCC country seems to have a different sectoral vocation or different sectoral interest. The UAE together with Bahrain have as top preference the 'Hospitality \& Leisure' industry, Oman and Qatar 'Architecture \& Engineering,' Kuwait 'Advertising/Marketing,' while Saudi Arabia respondents prefer ITC.

On the whole, the data from this report highlight a good propensity and attitudes towards entrepreneurship in the GCC countries, but it is still not enough. As a matter of fact, promoting entrepreneurship and creating entrepreneurs is not an easy task in practice, since social, cultural, political and economic factors influence the decision to become an entrepreneur. Certainly, quality education is fundamental to any country's long-term economic success because of the positive externalities in investment in knowledge and human capital.

\subsection{Entrepreneurship, SMEs and Start-ups in GCC Countries}

Today global competition requires major investment and spending in knowledge creation and innovation, as well as investment in capital formation.

Entrepreneurship is strongly related to entrepreneurial skills, which are very important for supporting the growth and development of firms, particularly small and medium-sized enterprises (SMEs), since significant numbers of small businesses have relatively underdeveloped entrepreneurship skills. After all, SMEs represent a very large part of the companies in the GCC region. They employ a large number of people and significantly contribute to the region's GDP. That is why SMEs are becoming increasingly important for GCC countries, and attract more attention from their governments. Today, SMEs can take advantage of the increasing fragmentation of production in global value chains. Yet small-scale entrepreneurs are survival entrepreneurs who are hampered by weak infrastructure, lack of finance, lack of capability, and lack of innovation. Instead, a dynamic set of SMEs can make a positive contribution to innovation, development and employment, but it is important that the innovation system is able to provide the incentives for small-scale entrepreneurs to become innovative. Policy and institutional environment are important determinants of innovative behavior.

GCC countries need more entrepreneurs to boost their competitive performance. While the GGC region is certainly more entrepreneurial than in the past, it remains insufficient compared to a global economy that has become altogether more entrepreneurial (Amorós and Bosma 2014; Singer, Amoròs, Arreola, 2015) . In the United States, Canada, Singapore, South Korea, Sweden, Switzerland, and in other innovation-driven economies many young companies are the creators and leaders of new industries, and most of these companies are high-growth, generating a great amount of jobs, innovations, patents and new technologies. Entrepreneurship in innovative industries like information technology and communication, "cloud computing," biotechnology, and renewable energy are driving many innovation-driven 
economies. Breakthrough or disruptive innovations often result from new firm startups, as Baumol (2005) pointed out. To unlock the potential for entrepreneurship in the GCC region it is necessary to foster a more entrepreneurial mindset among young people, reduce the stigma of failure, provide support for women, and promote legislation that make it easier to start a new venture and to transfer a business to new owners. Gulf countries have been trying in the last few years to develop a startup-fueled digital economy, but in general, still they have a long way to go. There are several reasons why GGC countries have fewer tech startups. The lack of an ecosystem and a base of skilled executives and product creators/managers contribute significantly to the scarcity of start-ups in these countries. In particular, engineers are the backbone of the digital revolution, Gulf countries have very little engineering talent available locally. However, a major factor is culture, which breaks down into a number of elements such as aversion to risk and the idea of ownership.

Other important factors, which are external and concern the enterprise environment, are: bureaucracy, bankruptcy laws, lack of capital, difficulty getting loans from banks and, more generally, unavailability of finance. Actually, although the region has a lot of capital going around, almost none is for seed-stage ventures. In addition, the lack of developers limits firms in the GCC region building high quality products themselves. Finally, the GCC countries need more research-focused universities, since technology development needs hosts of technologists.

However, in the entire GCC region, there is a growth of programs to support entrepreneurs and startup ventures, since public policies can contribute to shape the entrepreneurial process. The recent plans by the governments in Bahrain, Oman, Qatar, Saudi Arabia, and the UAE demonstrate that there is a strong will to support entrepreneurship and innovation with the aim of diversifying the economy. Gulf governments are giving greater attention to improving access to debt and equity finance. Governments are also developing mentoring and coaching programs to help new entrepreneurs or those experiencing fast growth (e.g. business incubators, business accelerators, etc.), and network initiatives to strengthen the competencies of co-located entrepreneurs through knowledge spillovers (e.g. cluster programs and science parks). Incubators, in particular, are very helpful for startups, since they can assist them in their initial phase of development, providing expertise in areas like technology and marketing. In addition, they help in raising seed funding, mentoring, and training. Science parks, instead, are major institutions that aim at promoting innovation and entrepreneurship at local level. Their role is to stimulate the flow of knowledge amongst universities, R\&D centers and enterprises. Although the empirical literature about their performance is controversial, they constitute key elements of the research-based development policy to foster the blooming of innovative start-ups and local clusters. Yet, education is key in the plans of GCC countries, since as we have seen in the survey by Bayt (2015), education can help very much in entrepreneurial activities.

The important role of government for education and entrepreneurship is highlighted in Teh, et. al. (2015), based on a survey of 135 students in Dubai. These authors found that entrepreneurial attitude is positively and significantly related to entrepreneurial intentions. Further, having a university playing a greater role in providing entrepreneurship training and assistance would also increase students' intentions to become entrepreneurs. In addition, the research revealed that, contrary to expectations, having a family member as an entrepreneur did not increase the respondents' intentions to be an entrepreneur themselves. An important implication of these findings is that governments and institutions can do much to foster more entrepreneurial intentions and, by extension, more entrepreneurial activity. Thus, greater attention can be paid to identifying potential entrepreneurs early during their education, and providing specialized training to encourage and develop their entrepreneurial skills. Finally, aside from specific entrepreneurship courses, the education system as a whole should be predicated on a curriculum to help their students develop autonomy, independent thinking, creativity, risk-taking, and the ability to learn from mistakes (Teh, et al., 2015).

Actually, the UAE is a country that has been favorably ranked on various economic and entrepreneurship indices, but it has the second lowest rate of established entrepreneurs compared to other innovation-driven economies (Teh, et al., 2015). However, in February 2015 the UAE's government launched a seven-point scheme to make innovation the driving force in schools and universities. In addition, the Government of Dubai developed Industrial Strategy 2030 in order to strengthen its still limited industrial sector, and implement its 2021 Vision. The strategy aims at making Dubai an international hub for knowledge-based innovation and sustainable industrial activities, and to create an attractive investment environment through a set of initiatives and incentives. This strategy aims at creating more than 27,000 specialized jobs, increase the research and development expenditures, and exports. Also, the UAE has seen a surge in start-up accelerators and incubators for technology companies. As an increasing number of incubators emerge, we can expect the quality and experience of the entrepreneurs to rise, and with them the risk attitude and the expertise of investors. The landscape of startups and enterprises in Dubai, and, in general, in the UAE, is changing quickly and positively in order to implement a more diversified and competitive economy. 


\section{Policies and Discussion}

In this section, we aim to identify the policies and the conditions that boost innovation, stimulate entrepreneurship and qualify the human capital in order to diversify and develop the non-oil private sector and improve the competitiveness of the GCC economies. Given the decline of revenues of these oil-exporting countries due to the decrease of oil prices, reforms are necessary to increase the pace of economic diversification and support job creation.

First of all, diversification needs improvements in the business climate. It also requires diversity in the production base, and the development of tradables. The development of a tradable sector is fundamental in bringing international competition into the local market, stimulating innovation and enhancing total factor productivity. Furthermore, although diversification is balanced within many sectors, it is often pursued "downstream," using cheap labor (for example in retail, hospitality, telecommunications) in all the economies of the GCC countries, even in the case of Dubai. A successful economic diversification, instead, must move "upstream" in the industry value chain, as it has been argued in section 2, employing qualified and skilled labor that increases productivity. The human capital and education aspect is thus critical in developing this process (Cherif, Hasanov, Zhu, 2016). It is also important that diversification go through the increase in exports of goods and services of high quality (Schilirò, 2013). All this requires a technological upgrade, since technology is a key factor, especially when it helps to improve the productivity and production efficiency, as in the case of automation in the manufacturing sector. In turn, this strategy involves investment by firms in upstream activities like R\&D and product testing, which are, in a sense, "cost" activities. Unfortunately, the GCC countries still have a limited propensity to support and invest in cost activities like R\&D. These activities necessitate a government policy aimed at developing innovation strategies that create a favorable innovation environment.

Another point is that most developed western economies rely on a tax-based system, in which firms are taxed as they make turnover/profits, and any investments in innovation capacity and assets are tax deductible. Thus, many western firms set aside tax savings to spend on R\&D, which, in turn, is further incentivized by the government. On the contrary, GCC countries often rely on a 'fee based system' in which firms are taxed before they even start. Under this system, the incentive to innovate and start a more complex business is deterred. Therefore, GCC governments need to change their system of taxation for the companies, in order to make it easier R\&D and innovation activities. In fact, as already mentioned above, a major aspect of the innovation policy is to increase R\&D expenditures across the countries of the Gulf region and to move the economies toward the global frontier of innovation; this implies fostering the creation of patents. Still, the support of general-purpose technologies, such as nanotechnology, biotechnology and information and communication technology, are vital. Improvements in skills and in education, particularly in the STEM areas, are also crucial.

A further point is that innovation upstream requires risk capital, which is still lacking in the GCC countries, though it is slowly emerging. Also, the role of financial markets and banks is very important for the growth and diversification of GCC economies (Hamdi and Hakimi, 2015; Mitra et al., 2016). The financing system (whether equity or loans) is key to a diversification/ innovation policy of a country, and has to develop in tandem with diversification and the innovation process. After all, we have seen that finance is a major problem for SMEs and new ventures (Bayt, 2015). Moreover, innovation policies can be enhanced through greater cooperation between the economies of the GCC, thus it is very convenient to create and strengthen networks for innovation among countries of the Gulf region. The cooperation and the networks can produce scale economies for R\&D and innovation activities, given the relatively small size of GCC countries.

Innovation and growth are also positively affected by FDI (Frenkel, et al., 2004; Goldberg, 2007). FDI are particularly important for the transfer of knowledge and expertise. They can contribute in new sectors and in upstream value chains of various industries with beneficial effects on diversification. An FDI policy is therefore necessary.

Good innovation policies start with good institutions: institutions matter (North (1990). This proposition is confirmed by the data shown in Cornell et al. (2016). Moreover, good institutions are crucial for innovation and entrepreneurship, and favor the economic growth of a country (North, 1990; La Porta, et al., 1999; Acemoglou et. al., 2001). A Triple Helix approach based on university-industry-government relationships (Etzkowitz, Leydesdorff, 1995; Ranga and Etzkowitz, 2013) can be very helpful for innovation, since innovation policy is strictly related to the capacity to create an 'innovation culture' with business, students and society at large. This theoretical framework provides endogenous development of technology and innovation. Etzkowitz, Leydesdorff (2000), in particular, prefer a balanced configuration in the positioning of the university, industry and government institutional spheres relative to one another. Such balanced configuration is specific to the transition to a 'Knowledge Society,' where university and other knowledge institutions act in partnership with industry and government. Thus, the hybridization of elements from university, industry and government can generate new institutional and social formats for the production, transfer and application of knowledge. In the end, we believe that there is no single model of innovation policy, but innovation policies and institutions need to be context specific, reflecting the extensive heterogeneity and varying trajectories of countries. 
As for entrepreneurship, the design of a reward structures more favorable to the development of entrepreneurs is strategic. Education is most helpful for entrepreneurial activities, this is why education is key in the plans of GCC countries (Bayt, 2015). Governments in the GCC countries should support entrepreneurship education at both the high school and college levels, as well as enhancing apprenticeship and experiential learning. In short, investing in human capital is primary to promote innovation and entrepreneurship and to foster economic growth. However, it is not an easy task and requires a long time to achieve good results in this field through appropriate policies. Yet, policies to reduce gender gaps and to attract foreign talents are just as important. In addition, GCC governments can help by providing entrepreneurial 'infrastructure' such as accelerators and incubators that offer space for entrepreneurs and linkages to mentors and potential customers. In general, the public-private partnership model is a strategic choice and can be a game-changer. Also, it is better at fostering bottom-up entrepreneurship that thrives on the creation of an open and competitive level playing field that gives space to potential local innovators. At the same time, the disruptive and remarkable nature of innovation that is more service-based and works from the bottom up should not be underestimated.

Finally, entrepreneurship and innovation policies must focus on SMEs in GCC economies, since SMEs are the backbone of such economies. It is fundamental to encourage the creation of innovative and high-growth new ventures of small and medium size, which are open to global markets, in the private non-oil sector. Moreover, the creation and funding of startups in the high-tech sector are valuable, since startups are gaining a major role for the advancement of innovation, qualified job creation and to stimulate entrepreneurial creative minds. Thus, it is necessary to implement an efficient startup ecosystem, where the regulatory frameworks are transparent, simple and helpful. In particular, the insolvency and the bankruptcy laws to allow company's internal restructuring must be improved across the GCC countries.

\section{Conclusions}

In this contribution, we have pointed out the importance of economic diversification for the oil-based GGC region made up of six high-income countries - to make their economies less reliant on volatile and uncertain hydrocarbon revenues. We have also supported the theoretical argument that innovation and entrepreneurship constitute major drivers to diversify and develop the GCC countries. A knowledge/innovation - driven economy, which is the kind of economy that GCC countries are trying to become, has technology, innovation and high-quality education as key factors. These countries need to expand the private sector, especially the non-oil tradable goods sector, boost competitiveness, create job opportunities, improve education in order to build the conditions for an environment conducive to innovation, and stimulate entrepreneurship with a particular focus on the small and medium enterprises. Our analysis highlights that the GCC countries have so far not performed satisfactorily in innovation. We have underlined that governments in the Gulf region can play an important role in developing a successful innovation strategy in order to create a healthy innovation environment. Further, the Triple Helix approach can be very helpful for knowledge and innovation generation in a country that aims to become knowledge-based. However, there is a great effort by the GCC governments to develop and implement strategies to improve the innovative capacity, given the decline and volatility in oil prices. Therefore, we have discussed the policies necessary to foster innovation and stimulate entrepreneurship in the GCC economies to diversify and enhance these economies.

As far as entrepreneurship, our analysis highlights that the GCC countries have a fairly significant propensity towards entrepreneurial activities and self-employment, but there are several barriers for starting businesses, of which the most frequent is the availability of funding. In addition, GCC countries should encourage the SMEs that open to global markets, and also foster high-tech start-ups. Finally, we have emphasized that the UAE's economy is changing quickly and in the right direction of diversification. All the other GCC countries (Saudi Arabia seems the readiest), taking into account the natural differences and the different vocation, should follow soon.

\section{Acknowledgments}

We wish to thank Helmi Hamdi, Maurizio Lisciandra and Alexandar Williams for their helpful comments and suggestions. The usual disclaimer applies.

\section{References}

Acemoglou, D., Johnson S., \& Robinson, J. (2001). The Colonial Origins of Comparative Development: an Empirical Investigation. American Economic Review, 91(5), 1369-1401. https://doi.org/10.1257/aer.91.5.1369

Acs, Z. J. (2006). How Is Entrepreneurship Good for Economic Growth?. Innovations, 1(1), 97-107. https://doi.org/10.1162/itgg.2006.1.1.97

Altomonte, C., Aquilante, T., Békés, G., \& Ottaviano, G. (2013). Internationalization and Innovation of Firms: Evidence and Policy. Economic Policy, 28(76), 663-700. https://doi.org/10.1111/1468-0327.12020

Amorós, J. E., \& Bosma, N. (2014). Global Entrepreneurship Monitor 2013 Global Report. Wellesley (MA): Babson 
College.

http://www.babson.edu/Academics/centers/blank-center/global-research/gem/Documents/GEM\%202013\%20Glob al\%20Report.pdf

Baumol, W. (2005). Education for Innovation: Entrepreneurial Breakthroughs Versus Corporate Incremental Improvement. In A. B. Jaffe, J. Lerner, \& S. Stern (eds.), Innovation Policy and the Economy, Volume 5, National Bureau of Economic Research, Cambridge (MA): MIT Press.

Bayt, (2015). Entrepreneurship in the MENA Survey. November. http://static.wamda.com/web/uploads/resources/Bayt_Entrepreneurship_Survey_2015.pdf

Callen, T., Cherif, R., Hasanov, F., Hegazy, A., \& Khandelwal, P. (2014). Economic Diversification in the GCC: Past, Present, and Future. IMF Staff Discussion Note, SDN/14/12, 1-32, December. https://doi.org/10.5089/9781498303231.006

Cherif, R., Hasanov, F., \& Zhu, M. (eds.) (2016). Breaking the oil spell. The Gulf Falcons' Path to Diversification. Washington, DC: International Monetary Fund.

Cornell University, INSEAD, WIPO, (2016). The Global Innovation Index 2016: Winning with the Global Innovation. Ithaca, Fontainebleau, Geneva: Cornell University, INSEAD, WIPO.

Drucker, P. (1985). Innovation \& Entrepreneurship, Practice \& Principles. New York: Harper \& Row.

Dubai SME, (2016). The State of SME Equity Financing in Dubai. Dubai: Dubai SME. http://www.sme.ae/Studies\&ResearchDocument/EQUITY_REPORT.pdf

Eaton, J., \& Kortum, S. (1999). International Technology Diffusion: Theory \& Measurement. International Economic Review, 40(3), 537-570. https://doi.org/10.1111/1468-2354.00028

Etzkowitz, H., \& Leydesdorff, L. (1995). The Triple Helix--University-Industry-Government Relations: A Laboratory for Knowledge-Based Economic Development. EASST Review, 14, 14-19.

Etzkowitz, H., \& Leydesdorff, L. (2000). The Dynamics of Innovation: from National Systems \& "Mode 2" to a Triple Helix of University-Industry-Government Relations. Research Policy, 29, 109-123. https://doi.org/10.1016/S0048-7333(99)00055-4

Fagerberg, J. (2004). Innovation: A guide to the Literature. In Fagerberg, J., Mowery, D., Nelson, R (eds.) The Oxford Handbook of Innovation. Oxford: Oxford University Press.

Fagerberg, J., Srholec, M., \& Verspagen, B. (2010). Innovation \& Economic Development. In B. Hall, N. Rosenberg (Eds.), Handbook of the Economics of Innovation. Vol. II. Amsterdam: North Holland. https://doi.org/10.1016/S0169-7218(10)02004-6

Frenkel, M., Funke, K., \& Stadtmann, G. (2004). A Panel Analysis of Bilateral FDI Flows to Emerging Economies. Economic System, 28(3), 281-300. https://doi.org/10.1016/j.ecosys.2004.01.005

Furnam, J. L., Porter, M. E., \& Stern, S. (2002). The Determinants of National Innovative Capacity. Research Policy, 31, 899-933. https://doi.org/10.1016/S0048-7333(01)00152-4

Goldberg, L. (2007). Financial Sector FDI \& Host Countries: New \& Old Lessons. FRBNY Economic Policy Review, 13(1), 1-17, March.

Hamdi, H., \& Hakimi, A. (2015). Did Banks \& Financial Markets Developments Lead to Economic Growth in MENA Region? Evidence from Dynamic Panel Data Estimation. MPRA Paper 64310, University Library of Munich, Germany.

Hanushek, E., \& Woesmann, L. (2015). Universal Basic Skills Should Become the Primary Development Goal. Vox, May 24.

Hesse, H. (2008). Export Diversification \& Economic Growth. Commission on Growth \& Development WP. No 21. Washington: World Bank.

IMF, (2015). The Regional Economic Outlook: Middle East \& Central Asia. Washington, DC: IMF, October.

IMF, (2016). World Economic Outlook. Washington, DC: IMF, April.

Kortum, S. (1997). Research, Patenting, \& Technological Change. Econometrica, 65(6), 1389-1419. https://doi.org/10.2307/2171741

La Porta, R., Lopez-de-Silanes, L., Shleifer, A., \& Vishny, R. (1999). The quality of government. Journal of Law, Economics \& Organization. 15(1), 222-279. https://doi.org/10.1093/jleo/15.1.222 
Lederman, D., \& Maloney, W. E. (eds). (2007). Natural Resources: Neither Curse nor Destiny. Washington, DC: World Bank, Stanford University Press.

Minguillo, D., Tijssen, R., \& Thelwall, M. (2015). Do Science Parks Promote Research \& Technology? A Scientometric Analysis of the UK. Scientometrics, 102(1), 701-725. https://doi.org/10.1007/s11192-014-1435-z

Mitra, P. Hosny, A., Minasyan, G., Fisher, M., \& Abaiyan, G. (2016). Avoiding the New Mediocre. Raising the Long-Term Growth in Middle-East \& Central Asia. Washington, DC: International Monetary Fund.

North, D. C. (1990). Institutions, Institutional Change \& Economic Performance. Cambridge: Cambridge University Press. https://doi.org/10.1017/CBO9780511808678

Porter, M. E., \& Stern, S. (2001). Innovation: Location Matters. MIT Sloan Management Review, July, 28-36.

Ranga, M., \& Etzkowitz, H. (2013). Triple Helix Systems: An Analytical Framework for Innovation Policy \& Practice in the Knowledge Society. Industry \& Higher Education, 27(4), 237-262. https://doi.org/10.5367/ihe.2013.0165

Schilirò, D. (2013). Diversification \& Development of The United Arab Emirates' Economy. Journal of Applied Economic Sciences Quarterly, IX(2), 228-239, July.

Schilirò, D. (2015). Innovation in Small \& Medium Enterprises in the United Arab Emirates. International Journal of Social Science Studies, 3(59), 148-160. https://doi.org/10.11114/ijsss.v3i5.1014

Schumpeter, J. A. (1939). Business Cycles. A Theoretical, Historical, \& Statistical Analysis of the Capitalist Process, New York: McGraw-Hill.

Schumpeter, J. A. (1942). Capitalism, socialism \& democracy. New York: Harper \& Brothers.

Singer, S., Amoròs, J. E., \& Arreola, D. M. (2015). Global Entrepreneurship Monitor 2014 Global Report. Babson Park (MA): Babson College.

http://www.babson.edu/Academics/centers/blank-center/global-research/gem/Documents/GEM\%202014\%20Glob al\%20Report.pdf

Teh, J., Al-Dhaafri, H., \& Isakovic, A. (2015). Entrepreneurial Attitudes \& Intentions of Dubai Students, In Proceedings of 9th Asia-Pacific Business Research Conference 5 - 6 November 2015. Bayview Hotel, Singapore. http://www.wbiworldconpro.com/uploads/singapore-conference-2015/management/1445858769.pdf

\section{Copyrights}

Copyright for this article is retained by the author(s), with first publication rights granted to the journal.

This is an open-access article distributed under the terms \& conditions of the Creative Commons Attribution license which permits unrestricted use, distribution, \& reproduction in any medium, provided the original work is properly cited. 